\title{
The Influence of Teacher Performance Appraisal and Development Implementation on the Secondary Students' Examination Scores in Public Schools in Kenya
}

\author{
Kimeli Matthew Chirchir and Solomon Letangule
}

\section{ABSTRACT}

The study sought to assess the influence of teacher performance appraisal and development implementation on the Secondary Students' Examination Scores in Public Schools in Kenya. The study specifically sought to determine the extent to which the appraisal of Teacher knowledge and application, appraisal on professional development of teachers and the appraisal of teachers' time management on Secondary Students' Examination Scores among public schools in Kenya. Optimizing descriptive cross-sectional survey research design, the study targeted all secondary school teachers in Kenya. The study adopted a simple random sampling technique using a ratio of 3:1 to ensure all the 200 schools were given a fair chance to participate in the study; further, a purposive sampling technique was also used to identify key informants. Primary data was collected through an online structured questionnaire. Qualitative and quantitative analysis was done by use of descriptive and inferential statistics respectively. The study concluded that appraisal of teachers' continuous professional development, appraisal of teachers' knowledge and application and the appraisal of teachers' continuous time management greatly influences their performance hence improving students' academic performance. The study recommends the enhancement of TPAD during the next review phase to embrace and connect parameters in the appraisal tool and students' examination scores. Further, TSC in liaison with the ministry of education and the respective school principals should take deliberate effort to plan and set aside funds to enhance professional training, workshops, seminars, and conferences through which the teachers will be enlightened on how to enhance their professional knowledge and application while considering independent evaluators to enhance credibility, validity and reliability of teacher rating.

Keywords: Appraisal and development, examination scores, teacher performance.

\section{INTRODUCTION}

\section{A. Background Information}

Improving worker performance is critical objective on organizations. Performance measurements remain a vital metric in performance management optimized as an index in analysis of employee performance (Dessler, 2008). Evaluation of performance focuses on measuring staff comportments and productivity in a definite period (Karimi, \& Hussain, 2011). World over, Performance appraisal systems for teachers is a critical undertaking; in the United States of America (USA), Teacher appraisals focuses on three tiers of teachers: newly employed, experienced and those who require support. In Nigeria just like the world over, the system of educational is exam-oriented; therefore, student performance in secondary school national examinations administered by West African Examinations Council
Published Online: November 16, 2021

ISSN: $2736-4534$

DOI : 10.24018/ejedu.2021.2.6.199

K. M. Chirchir*

Kenya School of Government, Baringo, Kenya.

(e-mail: mathew.chirchir@ksg.ac.ke) S. Letangule

Kenya School of Government, Baringo, Kenya.

(e-mail: solomon.letangule@ksg.ac.ke)

*Corresponding Author
(WAEC) becomes an important proxy parameter in measuring teachers' performance (Charlotte \& Mc-Greal, 2000).

Teachers Performance appraisal ratings provide a useful nexus to the contribution of teachers to student learning outcomes as long as the appraisal process incorporating establishing performance standards, communicating performance expectations, measuring actual performance, comparing real results with expected performance accompanied by commencement of remedial action is adhered (Surbhi, 2015).

For teachers to continue offering quality education, it is imperative they continue advancing their skill base through continuous education and training, failure to which may cause slur on examination results. Learning outcomes encompass what the learners can actually do with what they comprehend; an understanding upheld by reference (Donnelly \& Fitzmaurice, 2005). 
Most countries base evaluation of teacher performance on competencies, behavioural traits and their ability improve. Countries such as Australia in 2011 focused on professional engagement, knowledge, and practice (AITSL, 2012). A number of counties in USA adopt Danielson's framework focusing on parameters such as professional responsibilities, planning and preparation, classroom management and instructional strategy (Danielson, 2013).

Mills (2009) posits that success or failure among secondary school students relies on the quality of instruction obtained from professionally developed teachers as opposed to the lack of students' learning abilities. To spur better student examination scores through learning processes, teachers must have in-depth knowledge of pedagogy.

Performance by students on national examinations interests' stakeholders' majorly learning institutions and government since education play a bigger role in mounding character, technical skill, human intellect and effective citizenship (Ayeni, 2010).

Kayode and Ayodele (2015) observe that teachers' ability to manage time may have a positive effect on students' educational performance, time as an inadequate resource that affects numerous facets of human undertakings also affect the education sector.

The responsibility of employing and managing teachers in Kenya is vested in the TSC a government agency established through Article 237(1) of the Constitution of Kenya 2010. This commission is responsible for appraising the standards of education and training of personnel joining the teaching service, checking the behaviour and performance of educators in the education service among others (GoK, 2010; TSC, 2012).

In operationalizing this role in line with the tenets on the public sector results-based management (RBM), TSC rolled out Performance Contracting and TPAD in January 2016 as a vital aspect of change initiatives concerning sustainable provision of superior education in public learning institutions in Kenya (TSC, 2018). Juerges et al. (2004) observe that the implementation of such initiatives has led to less teacher absenteeism, better teamwork and effective preparedness by teachers' efforts supports the original intent of TPAD appraisal in enhancing teacher quality that possibly raises student examination scores.

The implementation of TPAD in Kenya both legislative and regulatory support; courtesy of the TSC Act (2012), TSC exercises its mandate on checking the behaviour and performance of educators in the education service; the commission is also required by the Code of Regulations for Teachers (2015) to develop and administer teachers' performance appraisal system a requirement that saw the development of TPAD.

In the year 2016, TSC commissioned TPAD that focused on teacher traits and six teacher behaviour traits. They include professional development, professional knowledge and application, teacher conduct, learner protection, safety, discipline, innovation and creativity in teaching, time management, collaboration with stakeholders and promotion of co-curricular activities. This study was limited to three of these traits namely: Teachers professional knowledge and application, continuous professional development, and time management.
The current Teacher evaluation system using the TPAD tool replaced the traditional performance appraisals that required head teachers or TSC county directors to perceptively rate teacher's performance making the process. TSC CEO asserts that TPAD has yielded a positive impact on learner performance despite teething problems subjective (TSC, 2016).

Student KCSE examination scores have been used over the years as a metric to estimate to establishing quality of teacher instruction. Increasingly, KCSE average scores have been used in awarding best performing students, subject teachers and institutions in various Sub-Counties. Smith and Kubacka (2017) notes that the practice of utilizing nationalized student examination results as an impartial parameter in educators' assessment is not exceptional to Kenya but also has progressively more been popularized as international testing philosophy. Despite all these efforts, there still exists an increasingly concern on the exact factors that impact students' educational performance in secondary school examinations. There has been a deliberate effort by researchers on this pursuit including (Kwedho, 2015) effectiveness of PC amongst secondary school educators; (Muraguri, 2015) on appraisal of PC in relative to educators' job performance in public tertiary institutions. Jonyo \& Jonyo (2017) who assessed the implications and challenges of performance management in Kenyan public schools. Despite this effort, neither of the studies zeroed on assessing the influence of teacher performance appraisal implementation on students' examination scores among the public secondary school teachers in Kenya, and a gap that this study seeks to address.

\section{B. Statement of the Problem}

Kenya is committed to achieving its Vision 2030 through the provision of quality education which prompts development from family to the societal level. However, this vision can only be achieved when students' examination scores $\mathrm{s}$ in secondary school allow them to transit to higher levels of learning. Consequently, the government of Kenya pays tuition fees for all students in secondary school, provides texts books and has partnered with Global Partners in Education through the Teachers Service Commission to develop a TPAD tool to monitor teachers' performance since it is critical in the provision of quality education. It is expected that the implementation of the TPAD tool will improve efficacy and build a performance-oriented culture and instil accountability in learning outcomes. Parents and other stakeholders strive to ensure quality education is achieved in the Country through the provision of needed infrastructure. With the existence, support from TSC and secondary school management on the consistent implementation of TPAD, it should be expected that such noble practice should translate to commensurate student examination scores s. However, students' examination scores in KCSE is still a mirage because only $19 \%$ i.e., 144, 033 out of 747,161 in the $2020 \mathrm{KCSE}$ scored $\mathrm{C}+$ which is the minimum entry to a university, yet teachers continuously fill the TPAD tool showing an average score of $80 \%$ which arguably should translate to good student examination scores. Most schools in Kieni West learners' scores do not measure up with the learners' KCSE scores (TSC, 2016). 
There could be some factors that lead to low examination scores among students in Kieni West Sub County, (Ngisa et al., 2017), despite consistent implementation of TPAD. There exist thin empirical studies on the influence of TPAD implementation on students' examination scores, however, such studies have often focused on Teacher performance as opposed to student examination scores, furthermore, and such studies are yet to focus on Kieni West nor variables under investigation in this study has not been investigated. Furthermore, some studies have linked teacher performance to students' achievement, but the influence of TPAD implementation on student examination scores and particularly comparison of teachers' scores in the TPAD and student examination scores in KCSE examinations have thinly been empirically investigated. Therefore, there exists an empirical evidence gap on particularly on the influence of TPAD implementation on students' examination scores; it is against this backdrop that the study aimed at assessing the influence of TPAD implementation on Secondary Students' Examination Scores in Kenya.

\section{Research Objectives}

The general objective of the study aimed at assessing the influence of teacher performance appraisal and development implementation on Secondary Students' Examination Scores in public schools in Kenya. The study specifically sought to:

i) To determine the extent to which the appraisal of knowledge and application on teachers influence students' examination scores in Kenyan public secondary schools.

ii) To determine the influence of appraisal on the continuous professional development of teachers on Secondary Students' Examination Scores in Kenyan public secondary schools.

iii) To explore the influence of the appraisal of teacher's time management on Secondary Students' Examination Scores among in Kenyan public secondary schools.

\section{LITERATURE REVIEW}

\section{A. Theoretical Framework}

The Goal Setting Theory (GST) by Locke in 1968 which proposes that goal setting is fundamentally correlated to job performance. According to this theory, value and value judgment are important cognitive determinants. (Okumbe, 1999); accordingly, employees are committed work so as to realize objectives. The theory suggests that employees should first set goals, then responds and performs towards the achievement of the goal (Locke et al., 1988).

Therefore, the Goal Setting Theory starts at value, and value judgments which build emotions to achieve goals set. When the goal is achieved, the results should reflect in the employee performance, responses, or actions, this gives feedback.

As applied in this study, the theory assisted the researcher to get feedback on the influence of implementation of TPAD on students' academic performance. This is because GST starts from values and value judgments which raises desires, similarly, the TPAD tool starts when teachers set targets based on teaching standards prescribed. The tool gives teachers clear expression of the baseline of expectations for the professional practice and conduct of teachers as Okumbe
(1999) postulates, workers who effectively participate in goal setting process, perform better. It is therefore anticipated that teachers should perform better in their duties. The goals set should raise teachers' desires, in this study effective implementation of TPAD should influence students' performance measured through students' achievement at KCSE.

\section{B. Review of Empirical Literature}

A comprehensive review of past studies on the variables under study was undertaken; the review was restricted to studies undertaken not more than ten years ago on the following areas.

\section{1) Teacher Knowledge Application and Student \\ Examination scores}

Olosehinde et al., (2018) conducted a study on teachers' knowledge indices as prognosticators of student's examination performances in Nigerian Kwara State. The purpose of the study was to establish the prognostic significance of teachers' mastery of teaching content and instructional knowledge on the performance in Maths and English. 78 English and Maths Teachers were sampled randomly from 32 secondary schools in Kwara State, Nigeria. In the study, the collection of quantitative data used vignettes, tests, and observations. Analysis of data was done by employing inferential and descriptive statistics. The study findings indicated that pedagogical and subject content influenced student examination scores.

Metzler and Woessmann, (2010) sought to find the effect of teacher subject understanding on student achievement. The study sought to establish the causal relationship between teacher-subject knowledge and student performance employing within-teacher, within-student variation. In the study, data from the 2004 Peruvian national evaluation was used. The sampled population for the study was 12,000 sixth graders, randomly sampled from 900 primary schools. Two subjects were tested: reading and math. The study findings indicated that there was a significant influence of the effect of teacher understanding on student examination performance.

Kuluo, (2018) studied the impact of teacher training and students' performance among Kenyan secondary schools. The study aimed to ascertain the effect of teacher training and student performance in public secondary schools in Narok County. The study engaged a descriptive research design. The study targeted 10 secondary schools in Narok County. The study sampled all principals, 50 trained and untrained teachers, as well as 384 students. Primary data was collected using questionnaires whereas secondary data was collected from the available performance records. Descriptive statistics were used to analyze data. The study findings indicated that there is a significant difference in teaching delivery between trained and untrained teachers.

Filgon et al., (2020) conducted a study on teachers' instructive content knowledge and students' examination performance. The study adopted a theoretical approach. The literature reviewed was from peer-reviewed journals because they were considered authentic. Subjects whose content pedagogy was considered in the study were geography, physics, and chemistry. The study findings indicated that 
teachers with high pedagogical content knowledge were better teachers. Therefore, students had better performance.

Tchoshanov, (2008) conducted a study on teacher knowledge and student achievement. The purpose of the study was to determine the patterns between teacher knowledge and student learning results. The study employed a mixed-methods design; the measures used were Texas Assessment of Knowledge and Skills (TAKS), Teacher observation protocol, teacher knowledge survey, and teacher reflections. The sample size for the study was 22 in-service teachers from high need and low-SES schools. The study findings indicate a connection between instructors' knowledge and students' results.

\section{2) Teacher Professional Development and Student Examination scores}

A study by Golob, (2012) on the effect of teachers' professional improvement on the outcomes of pupils at the National evaluation of Knowledge in Slovenia optimizing data from a sample representing $5.3 \%$ of the population from 24 elementary schools based on consistency in mathematics and mother tongue performance in the past five years concluded that professional improvement of teachers impacted the examination scores of students.

A study by Parish, (2013) on the impact of teacher professional development and student examination scores based on math and science curriculum-based assessments. Using a study sample of 260 teachers from public schools who teach third, fourth, and fifth-grade students' math and science. Through inferential and descriptive statistics, the study concluded that time spent in the professional development of teachers was directly proportional to the examination scores of the students in CBAs.

Karamanos, (2020) undertaking a study on the influence of professional improvement approaches on student performance in mathematics elementary public schools in New Jersey utilizing an online survey to review the effect of content taught in professional development programs on students' performance established that content delivered in the development program influenced student academic performance.

Lu et al., (2017) studied the impact of teacher development programs on students' results in rural China. Study intended to assess the impact of the National Teacher Training Program (NTTP) on the academic performance of students in rural China. The study sampled 3,066 st6udents and 84 teachers from one Western province. A survey system was used to collect data, and it was in two phases: baseline and end-line survey. Regression analysis was used to analyze data. The findings indicated that the NTTP program did not influence the educational achievement of the students.

Oluwole et al., (2017) sought to find the effect of teachers' professional development on students' examination performance. The goal of the study was to establish the extent professional development of teachers affected the examination scores of students in Nigerian Benue and Nasarawa states. The study adopted a descriptive survey design. The target population was 8,335 teachers from 709 secondary schools. From the population, a sample of 417 teachers were respondents. Data was collected using questionnaires. Analysis of data was done by employing inferential and descriptive statistics. The study findings indicated that attendance of professional development by teachers influenced performance by learners.

\section{3) Teacher Time Management and Student Examination scores}

A study by Adams and Blair, (2019) on the effect of time management on the performance of undergraduate engineering students' employing correlation analysis, regression evaluation, and model discount established a strong correlation between time management behaviors and higher grades. Alani et al., (2020) investigating the association between management of time and students' examination scores in Oman's Sohar University with performance of students virtuously based on their selfmanagement and their efforts established time management correlates with academic performance necessitating the need for students' to properly manage time and parents supporting their children by minimizing assigned home chores.

A cross-sectional survey by Alyami et al.,(2021) examined the influence of time management on the student's academic performance established $75.4 \%$ of students had GPAs $4.5-5$ in 2020 . While $37.3 \%$ agreed they managed their time. $69.2 \%$ students with 4.5 - 5 GPA agreed they met their deadline (pvalue $=0.005)$ and $36.7 \%$ students with $4-4.5$ GPA strongly professed that poor planning led to low academic performance $(p$-value $=0.005) .66 .3 \%$ of learners with 4.5 to 5 GPA strongly agreed (p-value 0.047 ) to make a calendar or to-do list.

Cyril, (2015) conducted a study on time management and examination scores of higher secondary students. The study results indicated a significant relationship between the management of time and higher secondary students' performance in examination.

De Guzman and Guy, (2013) undertook a study on teacher's time management and student's performance in examination in LPU College of nursing focusing on evaluation of time management to present performance in examination of nursing students in the nursing professional subjects; to test the relationship of the nursing professors' time management styles in the university and the examination scores of students and to suggest a package to improve management of classroom of professors of nursing in the university.

Gayef et al., (2017) studied the association between time management capabilities and the educational success of the learners in the Vocational School of Health Services. In this research, it was established woman students' time wastage average scores were significantly higher than men's; though interestingly women students' academic performance was significantly higher than men; the findings also indicate difference in time management/planning between first and second year students', metropolitan and province dwellers, however, there's no substantial distinction among college students' time management subscales suggest rankings and academic fulfilment in keeping with their operating fame, grade, program, the educational reputation of mother and father.

Kayode and Ayodele, (2015) studied the effects of teacher time management on students' examination performance in Nigeria's secondary schools in Ekiti State, Nigeria. The findings showed a significant correlation between time management by teachers and the educational performance of 
students. The level of time management by teachers and the academic performance of students wares moderate.

Nasrullah and Khan, (2015) carried out a study on the impact of time management on students' examination scores s. The findings revealed that management of time is very significant, and it may affect the overall performance and achievements of an individual. Effective management of time is essential for students to perform well. Nevertheless, several students lack effective skills in the management of time which affect their academics and their life negatively. Using time by students in institutions of higher learning is related to their activities and daily routines. Management of time by students can also affect the strain level of students as they need to deal with their tasks and their achievements.

Ngowo, (2013) examined the correlation between time management and performance in academics for primary schools in Morogoro municipality. The results revealed the existence of wasters of time to the students and teachers, latecomers, and absentees for both students and teachers, the act of postponing activities of the school, supervision ineffectiveness by teachers and parents, education officers, lack of adherence to schools' regulations and rules as well as lack of motivation particularly to the educators, have led to the poor learning and teaching performance for students and teachers respectively in schools.

Oyuga et al., (2016) studied the association between the management of time and academic performance among bereaved students in secondary schools of Kenya. The study outcomes indicated a high positive association amongst management of time and examination performance among bereaved students in secondary schools. Ministry responsible for education should in generally understand the predicament of orphans and offer these learners enhanced services such as professional counselors capable of providing orphaned children appropriate and effective counseling services.

Razali et al., (2018) studied the influence of time management on students' performance in examination in Malaysia. The analysis results showed three principal elements related to time management which can be categorized as time-making plans, time attitudes, and time wastage. The findings also revealed that the races and gender of learners reveal no substantial differences in behaviors of time management. While faculty and year of study of learners revealed substantial differences in the behaviors of time management, time management behaviors albeit weak were significantly and positively correlated to the instructional fulfilment of students.

\section{4) TPAD Implementation and Student Examination scores}

Two almost similar studies undertaken in two different regions in Kenya focusing on TPAD and learning outcomes in Baringo and Kisii counties in Kenya yielded somewhat association between the two variables (Morara, 2018; Odunga et al., 2020).

Kareithi, (2018) while conducting a study on the effect of performance appraisal on the performance of secondary schools' teachers in Kenya established significant positive relation between goal setting, performance feedback and reward system practices and teachers' performance. In the study, she investigated the consequences of goal setting practices, performance feedback practices and reward system practices on the performance of secondary school teachers, however, the current study sought to establish the influence of TPAD implementation on Students' examination scores measured through KCSE examination. While she concentrated on teachers' performance the current study is interested in students' performance.

Some studies have linked teacher performance to students' achievement but the influence of TPAD implementation on student examination scores and specifically comparison of teachers' scores in the TPAD and student examination scores in KCSE examination has thinly been empirically studied or investigated. Therefore, there exists an empirical evidence gap particularly on the influence of TPAD implementation on student examination scores. This, therefore, highlights the need for this study.

\section{Research Methodology}

Optimizing descriptive cross-sectional survey research design (Oso, 2016) due to the researchers need to investigate different views on TPAD implementation and its influence on students' examination scores. The target population constituted all secondary school teachers in Kieni West Sub County in Nyeri County (Sekaran \& Bougie, 2010). Kieni west Sub County is divided into four educational zones with each comprising six secondary schools. Therefore, the study adopted simple random sampling technique (Saunders \& Lewis, 2019) using a ratio of 3:1 to ensure all schools were given a fair chance to participate in the study within educational zones, further, purposive sampling technique was also used to select four curriculum support officers based at the zones who were reached through Kieni West sub-county TSC office. Applying (Best and Kahn, 1998) 30\% formula (Sample Size $=30 \%$ of 666 ) the study arrived at a sample size of 200 secondary school teachers.

In the study, primary data was collected through structured questionnaire (Kothari, 2004). The questionnaire was considered suitable due to ease in the collection of data from huge samples and diverse regions and its ability to provide for greater homogeneity of questions, hence guarantee a higher equivalence of the data given by the respondents. The questionnaires comprised of five sections: Part I background information, part II - Teacher knowledge application and examination scores, part III-time management and student examination scores, Part IV professional development and student examination scores, part V-TPAD implementation, and student examination scores. Part II-V covered the research objectives with items rated on a Likert scale. The scale included the following; strongly disagree, disagree, neutral, agree, and strongly agree. At the end of the questionnaire, respondents were to provide mean scores of their schools in 2015 before the inception of TPAD and the most recent mean score in 2020.

During the collection of data, the researcher administered the data collection instrument through Google forms due to the need to comply with the ministry of health protocols to curb the spread of Covid-19. The link to google forms link https://docs.google.com/forms/d/e/1FAIpQLSdSm6ydn8_C ungI3Tujt7Zj2HQpnW0bSmU3s3D4zrx2WcBhOA/viewfor $\mathrm{m}$ ? usp=sf_link was shared through social media platforms such as WhatsApp and email. The rationale for the use of 
Google forms is to ensure convenience to the researcher and respondents (Hai-Jew, 2020) neo-covid 19. It also ensures strict adherence to Covid-19 protocols that minimize physical meetings.

The questionnaire used was piloted in a school randomly sampled in a Sub-County in Kieni West. Participating teachers ware $1 \%$ of the study sample (Orodho, 2017). This facilitated the testing of the instrument's validity and reliability (Orodho et al., 2016; Young, 2009).

The validity of the research instrument was established through peer and expert review at the Kenya School of Government (KSG) Baringo (Ogula et al., 2018; Sangoseni et al., 2012). The test-retest method was used to determine the reliability of instrument results. The method involved administering the questionnaires through google forms twice in a week to a group with similar characteristics as the respondents of the study and in an almost similar research setting.

Data were coded and entered into SPSS Version 20.0 for analysis. Both qualitative and quantitative data were collected. Qualitative and quantitative analysis was done by use of descriptive and inferential statistics respectively. Information is presented by the use of tables, pie charts and graphs; statistical indices such as percentage, the t-test and Ftest were also used.

Teachers were invited to participate voluntarily in the study through the google platform, teachers were assured that any information provided would only be used for the study and their responses would be treated with confidentiality. The researchers were objective and ensured that the findings of the study were solely based on the data collected.

\section{DAta ANAlysis: Presentation AND Discussion}

\section{A. Demographic Characteristics of Respondents}

The findings established 138 respondents, 91 were male while 47 were female, indicating that $65.94 \%$ males responded to the questionnaire while $34.06 \%$ females responded. From the results, it was evident that more males are teaching in secondary schools than females in Kieni West Sub County.

TABLE I: TYPE OF SCHOOL

\begin{tabular}{ccc}
\hline \hline & Frequency & Percent \\
\hline \hline National & 4 & 2.90 \\
Extra County & 26 & 18.84 \\
County & 28 & 20.29 \\
Sub-county & 80 & 57.97 \\
Total & 138 & 100.0 \\
\hline \hline
\end{tabular}

Source: Field data (2021).

From Table I, sub-county schools had more respondents than any other type of school it gave $57.97 \%$ of total respondents. Whereas national schools provided $2.9 \%$ of the respondents. Based on the findings, it is clear majority of the secondary schools in Kieni Sub-County are under the category of sub-county schools.

\section{B. Teacher Professional Development and Examination Scores}

The research sought to examine the extent to which teacher professional development influences examination scores among the students in Kenyan public secondary schools presented in Table II.

TABLE II: TEACHER PROFESSIONAL DEVELOPMENT AND EXAMINATION

\begin{tabular}{|c|c|c|c|}
\hline \multicolumn{4}{|l|}{ SCORES } \\
\hline Professional development of teachers & $\mathrm{N}$ & Mean & $\begin{array}{c}\text { Std. } \\
\text { Deviation }\end{array}$ \\
\hline $\begin{array}{l}\text { Attending subject symposia influence } \\
\text { student examination scores }\end{array}$ & 138 & 1.91 & 0.422 \\
\hline $\begin{array}{l}\text { Attending teacher Professional } \\
\text { development activities at the school level } \\
\text { influences student examination scores }\end{array}$ & 138 & 4.31 & 0.728 \\
\hline $\begin{array}{l}\text { Enrolling in a recognized/relevant } \\
\text { professional courses by teachers influence } \\
\text { student examination scores }\end{array}$ & 138 & 2.67 & 0.701 \\
\hline $\begin{array}{l}\text { Engaging in peer learning at zonal level } \\
\text { influences student examination scores }\end{array}$ & 138 & 3.9 & 0.842 \\
\hline $\begin{array}{c}\text { Engaging in KNEC and KICD activities } \\
\text { process influence student examination } \\
\text { scores }\end{array}$ & 138 & 3.71 & 0.501 \\
\hline Valid N (listwise) & 138 & 3.23 & 1.216 \\
\hline
\end{tabular}

Source: Researcher, 2021.

Findings in Table II indicate majority of the respondents by a mean of 1.91 (standard deviation 0.422) strongly disagreed that attending subject symposia determines students' examination scores. A rating indicating a mean of 4.31 (standard deviation 0.728) also identified that respondents agreed that when teachers attend teacher professional development activities at the school level affects student examination scores, and this might be because the school is following a set-out curriculum. However, a mean $=2.67$ with standard deviation of 0.701 , shows that respondents disagreed that teachers enrolling in recognized/relevant professional courses influence student examination scores. Majority of the respondents agreeing that engaging in peer learning at zonal level influence student examination scores with the mean 3.90 (standard deviation 0.842) and engaging in KNEC and KICD activities process is agreed to by a majority of the respondents that it influence student examination scores by approval of mean 3.71 (Standard Deviation 0.501).

A study by Golob, (2012) revealed that continuous professional development is a main factor in defining student performance because the more academically qualified the teacher has much more information about useful teaching methods as opposed to academically less competent teachers. The findings above have shown that although teachers are professionally qualified, professional development is necessary.

To establish whether there's any relationship between professional development of teachers and students' examination scores in Kenyan public secondary schools, the two numerical indexes (Professional development of teachers and Students' examination scores) were correlated by using Pearson's moment correlation coefficient as shown in Table III.

As per Table III, the Pearson correlation index obtained was $604(r=0.604)$. This suggested a great correlation which means that students' examination scores rose with the professional development of teachers. Its significance pvalue was 0.000 which was a bit less than p-value 0.01 . Indicating a degree of significance. This means that students' 
examination scores in Kenyan public secondary is significantly linked to professional development of teachers.

TABLE III: PEARSON MOMENT CORRELATION FOR PROFESSIONAL DEVELOPMENT OF TEACHERS

\begin{tabular}{|c|c|c|c|}
\hline & & $\begin{array}{c}\text { Students' } \\
\text { examination } \\
\text { scores }\end{array}$ & $\begin{array}{c}\text { Professional } \\
\text { development of } \\
\text { teachers }\end{array}$ \\
\hline \multirow{3}{*}{$\begin{array}{c}\text { Students' } \\
\text { examination } \\
\text { scores }\end{array}$} & Pearson Correlation & 1 & $604 *$ \\
\hline & Sig. (2-tailed) & & 000 \\
\hline & $\mathrm{N}$ & 138 & 138 \\
\hline \multirow{3}{*}{$\begin{array}{c}\text { Professional } \\
\text { development of } \\
\text { teachers }\end{array}$} & Pearson Correlation & $604 * *$ & 1 \\
\hline & Sig. (2-tailed) & 000 & \\
\hline & $\mathrm{N}$ & 138 & 138 \\
\hline
\end{tabular}

The study findings concur with those of Parish, (2013) and Karamanos, (2020) who found out that continuous teacher development had a positive effect on student performance. Nevertheless, they disagree with the study findings by Lu et al., (2017) which indicated that teacher development programs did not influence student examination scores.

\section{Teacher Knowledge and Application on Examination Scores}

The current study objective was to explore the extent to which teacher knowledge and application affects students' examination scores in Kenyan public secondary schools. This was done on a maximum scale of 5 wherein SA $=$ Strongly agree $\mathrm{A}=$ Agree $\mathrm{U}=$ Undecided $\mathrm{D}=$ Disagree $\mathrm{SD}=$ Strongly disagree. Table IV presents findings from respondents on the extent to which appraisal of knowledge and application affects students' examination scores in public secondary schools.

TABLE IV: TEACHER KNOWLEDGE AND APPLICATION AND STUDENTS' EXAMINATION SCORES

\begin{tabular}{|c|c|c|c|}
\hline $\begin{array}{l}\text { Teacher knowledge and application } \\
\text { and students' examination scores }\end{array}$ & $\mathrm{N}$ & Mean & $\begin{array}{c}\text { Std. } \\
\text { Deviation }\end{array}$ \\
\hline $\begin{array}{l}\text { Preparation and proper adherence to } \\
\text { schemes of work influence student } \\
\text { academic performance/achievement }\end{array}$ & 138 & 4.00 & 1.244 \\
\hline $\begin{array}{c}\text { Preparation of lesson notes influences } \\
\text { student examination scores }\end{array}$ & 138 & 4.20 & 0.844 \\
\hline $\begin{array}{l}\text { Marking/ checking learners work } \\
\text { influences student examination scores }\end{array}$ & 138 & 4.64 & 1.376 \\
\hline $\begin{array}{l}\text { Effective lesson planning influences } \\
\text { students }\end{array}$ & 138 & 4.29 & 0.932 \\
\hline Examination scores & & & \\
\hline $\begin{array}{l}\text { Teachers' subject/content mastery } \\
\text { influences student examination scores }\end{array}$ & 138 & 4.12 & 1.032 \\
\hline Valid N (listwise) & 138 & 4.25 & 1.316 \\
\hline
\end{tabular}

Source: Field data, 2021.

The results in Table IV show that preparation of lesson notes and its influence on the achievement of education among students ranged between 4.20 (1.376) (close to strongly agree that the preparation of lesson notes has a strong effect on examination scores among students). Marking/checking learners' work influences student examination scores strongly, this is shown by a mean of 4.64 (0.844) approximately 4 which is strongly agree that 'marking/checking learners' work influences students' examination scores. The findings indicated that the respondents agree that teachers' subject/content mastery influences the students' examination scores, as it is represented with a mean (4.12). Preparation and proper adherence to schemes of work influence student examination scores on which is displayed by a mean of 4.00 and standard deviation of 1.244. This shows that students may academically improve due to teachers' preparation and proper adherence to schemes of work in school.

The overall effect of teacher knowledge and application on students' examination scores was 4.25 (1.316) indicating that most respondents agreed that teacher knowledge and application affected students' examination scores. Most of those affirmations made by the respondents show that teacher knowledge and application circumstances affect educational attainment. Therefore, the higher teacher knowledge and application is linked to better examination scores $\mathrm{s}$ by students in public secondary schools in Kenya.

To find out more whether appraisal of knowledge and application and students' examination scores has a relationship, the two numerical indexes (teacher knowledge and application and examination scores) were correlated using Pearson's moment correlation coefficient as shown in Table V.

TABLE V: PEARSON MOMENT CORRELATION FOR TEACHER KNOWLEDGE AND APPLICATION

\begin{tabular}{|c|c|c|c|}
\hline & & $\begin{array}{c}\text { Academic } \\
\text { achievement }\end{array}$ & $\begin{array}{c}\text { Teacher } \\
\text { knowledge and } \\
\text { application }\end{array}$ \\
\hline \multirow{3}{*}{$\begin{array}{c}\text { Academic } \\
\text { achievement }\end{array}$} & Pearson Sig. & 1 & $621^{\prime \prime}$ \\
\hline & (2-tailed) & & 000 \\
\hline & $\mathrm{N}$ & 138 & 138 \\
\hline \multirow{3}{*}{$\begin{array}{c}\text { Teacher } \\
\text { knowledge and } \\
\text { application }\end{array}$} & Pearson & $621 * *$ & 1 \\
\hline & correlation & 000 & \\
\hline & $\begin{array}{c}\text { Sig. (2-tailed) } \\
\mathrm{N}\end{array}$ & 138 & 138 \\
\hline
\end{tabular}

**Correlation is significant at the 0.01 level (2-tailed).

Source: Field data, 2021.

As shown in Table $\mathrm{V}$, the Pearson correlation index received was $621(\mathrm{r}=0.621)$. Being strong suggests a positive correlation. This means students' examination scores rose with the frequency of teacher knowledge and application. Its significance or perhaps $\mathrm{p}$-value was 0.000 which is much less than alpha 0.01 . This meant that students' examination scores were significantly related to teacher knowledge and application.

This means that effective teacher knowledge and application are more important for student's examination scores through reducing learning difficulties. The study findings concurred with those of Metzler and Woessmann (2010) and Filgona et al. (2020) who found out that teacher subject knowledge had a significant influence on student achievement.

\section{Teacher Time Management and Examination Scores}

The research sought to examine the extent to which teacher time management influences examination scores among the students in Kenyan public secondary schools as presented in Table VI.

From Table VI, effective scheduling of assignments influences student examination scores greatly with a mean of 4.71 and SD of 1.283 .

TABLE VI: TEACHER TIME MANAGEMENT AND EXAMINATION SCORES Teacher time management Std. 


\begin{tabular}{cccc}
\hline \hline & & & Deviation \\
\hline \hline $\begin{array}{c}\text { Timely syllabus coverage influences } \\
\text { student examination scores } \\
\text { Teacher's level of time management } \\
\text { determines student examination } \\
\quad \text { scores }\end{array}$ & 138 & 3.99 & 0.822 \\
$\begin{array}{c}\text { Attending lesson in time (punctuality) } \\
\text { influence student's examination } \\
\quad \text { scores }\end{array}$ & 138 & 3.65 & 0.922 \\
$\quad \begin{array}{c}\text { Proper adherence to class timetable } \\
\text { influences student examination scores } \\
\text { Effective scheduling of assignment } \\
\text { influence student examination scores } \\
\quad \text { Valid N (listwise) }\end{array}$ & 138 & 4.01 & 0.946 \\
\hline \hline
\end{tabular}

Source: Researcher, 2021.

The teacher's level of time management determines student examination scores by a mean of 4.12 and SD of 0.922 . The respondents also showed agreement with the statement that proper adherence to class timetable influences student examination scores with a mean of 4.01 and SD of 0.946 . On the statement on whether timely coverage of the syllabus influenced student examination scores, most respondents agreed with the statement with a mean of 3.99 and standard deviation of 0.822 . Finally, on the issue of attending lessons on time (punctuality) influences student's examination scores; the mean for the response was the lowest at 3.65 with a standard deviation of 1.231. This inferred that most respondents were not sure whether punctuality in attending lessons influenced student examination scores.

Correlation analysis was used to establish the association between teacher time management and learners' academics in Kenyan public secondary schools. Pearson's moment correlation coefficient as shown in Table VII.

TABLE VII: PEARSON MOMENT CORRELATION FOR TEACHER TIME MANAGEMENT

\begin{tabular}{cccc}
\multicolumn{4}{c}{ MANAGEMENT } \\
\hline \hline & $\begin{array}{c}\text { Students' } \\
\text { examination } \\
\text { scores }\end{array}$ & $\begin{array}{c}\text { Teacher time } \\
\text { management }\end{array}$ \\
\hline \hline Students' & Pearson Correlation & 1 & $846^{*}$ \\
examination & Sig. (2-tailed) & & 000 \\
scores & N & 138 & 138 \\
Teacher time & Pearson Correlation & $846^{* *}$ & 1 \\
management & Sig. (2-tailed) & 000 & 138 \\
\hline \hline
\end{tabular}

Source: Field data, 2021.

As per Table VII, the Pearson correlation coefficient $(\mathrm{r}=$ 0.846). The level of significance is 0.000 . A correlation coefficient of more than 0.7 implies that the correlation between the independent and dependent variable is positive and very strong. In this case, the correlation between time management by teachers and the examination scores of students has a very strong positive correlation. Besides, the degree of significance is at 0.000 which is less than 0.05 , this implies that the correlation is significant statistically. The study findings concur with the findings by Razali et al. (2018) who found out that proper time management in schools had a substantial effect on the educational performance of students in Malaysia.

\section{Summary, CONCLUSION AND ReCOMmENDATION}

\section{A. Summary of Findings}

The findings indicated more male teachers responded to the questionnaire than their female counterparts which showed that more male teachers were teaching in secondary schools in Kieni West Sub County.

The findings also showed there were respondents from all categories of secondary schools. These were National schools, Extra County, County and Sub-county schools. From the data collected there were more respondents from subcounty secondary schools and very few from National schools which indicated that there were more sub-county schools in Kieni West Sub-county than any other category of secondary schools.

The findings on the effect of teachers' professional knowledge and application on students ' examination scores; included the influence of the following on students' achievement; preparation and adherence to schemes of work, preparation of lesson notes, mastery of content by the teacher, lesson plan development and usage, marking or checking students work and adequate syllabus coverage. The findings showed that the bulk of teachers' respondents agreed teacher's professional knowledge and application had an influence on the academic performance of the students.

The findings on teacher professional development on the students' examination scores; these included variables like attending symposia, attending to teacher professional development at school, enrolling for professional courses, peer learning at the zone level and participating in KNEC and KICD activities. The findings showed that a large number of the respondents agreed that teacher professional development in terms of peer learning at the zone level, participating in KNEC and KICD activities and continuous teacher professional development at school had a positive influence on learner achievement. However, the majority disagreed that attending symposia and enrolling for professional courses determined students' examination scores.

The findings on the influence of teachers' time management on students' examination scores which included the following: time management by the teacher, attending to lessons on time, adherence to class timetables and scheduling of assignments indicated that a majority of the teachers agreed that teachers' time management affected or influenced the examination scores of the learners. The findings indicated that the majority of the teachers agreed that time management by the teacher, scheduling of assignments and timely syllabus coverage greatly influenced the learners' examination scores. However, the majority of the teachers were not sure whether attending lessons on time influenced the achievement of the learners.

As per the results presented by the respondents in the mean scores of the Kenya national examination in 2015 and 2020, it was notable that the majority of the schools had their learners' results improve when 2015 and 2020 results are compared; a few dropped in performance; another percentage had their results remain within the same range. This, therefore, indicated that there were other factors apart from teacher Performance Appraisal Development that influenced the achievement of the learners. 


\section{B. Teacher Knowledge Application and Student Examination Scores}

The study findings indicated the influence of preparation of lesson notes on examination scores among students, most respondents agreed with the statement with a mean of 4.20 and a standard deviation of 1.376. The findings further indicated that the respondents agreed that teachers' subject/content mastery influences the students' examination scores, as it had a mean (4.12). Preparation and proper adherence to schemes of work influence student examination scores on which is displayed by a mean of 4.00 and standard deviation of 1.244. The overall mean of aspects of teacher knowledge and application on students' examination scores was 4.25 and $\mathrm{SD}$ of 1.316 indicating that most respondents agreed that teacher knowledge and application affected students' examination scores. From the correlation matrix of teacher knowledge application and student examination scores; the correlation coefficient is 0.621 at a significance level of 0.01 . This is a strong positive correlation that is statistically significant. Thus, teacher knowledge application has a positive and significant influence on student examination scores.

\section{Teacher Professional Development on Students' Examination Scores}

The study was conducted to assess the Teacher Professional Development on Students Examination scores and the study findings indicated that most respondents agreed that when Teachers attend the Teacher Professional Development activities at School levels affects Student's examination scores with a rating indicating mean of 4.31 and a Standard Deviation of 0.728 because it follows a given setout curriculum. The respondents also agreed that engaging peer learning at the zonal level influenced the students' achievement with the mean of 3.90 and Standard Deviation of 0.842 and also, engaging KNEC and KICD activities influenced Student Examination scores by a mean of 3.71 and Standard Deviation of 0.501 .

\section{Teacher Time Management on Student Examination Scores}

Under this objective, the study sought to examine the extent to which teacher time management influences examination scores among the students in Kenyan public secondary schools. The study results indicated that effective scheduling of assignments influences student examination scores greatly with a mean of 4.71 and SD of 1.283 . The teacher's level of time management determines student examination scores by a mean of 4.12 and SD of 0.922 . Proper adherence to class timetable influences student examination scores with a mean of 4.01 and SD of 0.946 . A mean of 3.99 and a standard deviation of 0.822 agreed that timely coverage of the syllabus influenced student examination scores. Finally, a mean of 3.65 with a standard deviation of 1.231 agreed that attending lesson in time (punctuality) influence student's examination scores. The study results correlates teacher time management and students' academics in Kenyan public secondary schools revealed that there is a significant statistically strong positive correlation between teacher time management and examination scores of students $(\mathrm{r}=0.846, \mathrm{p}<0.05)$.

\section{CONCLUSION}

The study was conducted to assess the influence of TPAD on students' examination scores, based on the study objectives the following conclusions were drawn:

1. On continuous professional development, the study concludes that appraisal of teachers' continuous professional development greatly improves students' academic performance as teachers had a good mastery of the content.

2. On teachers' knowledge and application, the study concludes that appraisal of teachers' knowledge and application greatly increases students' examination scores through reducing learning difficulties.

3. On time management, the study concludes that the appraisal of teachers' continuous time management greatly influences their performance hence improving students' academic performance through lesson attendance as well as in syllabus coverage.

\section{RECOMMENDATIONS}

The study recommends the enhancement of TPAD during the next review phase to embrace and connect parameters in the appraisal tool and students' examination scores The TPAD could be enhanced to further provide feedback that is frequent, timely, and includes specific suggestions on how to improve the content and subject knowledge instructional strategies, classroom management strategies, and recommendations for finding resources or professional development opportunities.

TSC in liaison with the ministry of education and the respective school principals should take a deliberate effort to plan and set aside funds to enhance professional training, workshops, seminars, and conferences through which the teachers will be enlightened on how to enhance their professional knowledge and application.

Secondary school head teachers in liaison with teachers need to inculcate that culture on effecting time management amongst students and teachers to spur student examination scores.

With the growing confidence in TPAD ratings and subsequent related spillover benefits, TSC should establish strengthen the department responsible for monitoring and evaluation or source for independent external evaluation services to remove possible bias and create credibility, validity, and reliability of teacher rating.

\section{CONFLICT OF INTEREST}

We authors declare we do not have any conflict of interest.

\section{REFERENCES}

Adams, R. V., \& Blair, E. (January-March, 2019). Impact of time management behaviours on undergraduate engineering students' performance. SAGE Open. 1-11.

AITSL, (2012). Australian teacher performance and development framework. Carlton South, Australia; ESA.

Alani, F., Khan, F., \& Hawas. A. (2020). Do time management factors impede students' academic achievement? A case-study - Sohar University, Oman. Humanities \& Social Sciences Reviews, 8 (4), 201212. 
Alyami, A., Abdulwahed, A., Azhar, A., Binsaddik, A., \& Bafaraj, S. (2021). Impact of time-management on the student's academic performance: a cross-sectional study. Creative Education, 12, 471-485. Doi: 10.4236/ce.2021.123033.

Ayeni, A. J. (2010). Teachers' instructional task performance and principals' supervisory roles as correlates of quality assurance in secondary schools in Ondo State, Ph.D. Dissertation, Dept of Educational Management, Faculty of Education, Obafemi Awolowo Univ., Ile-Ife, Nigeria.

Best, J. W., \& Kahn, J. V. (1998). Research in Education, $8^{\text {th }}$ ed. London, U.K: Allyn \& Bacon.

Charlotte, D., \& Mc-Greal T. L. (2000). Teacher evaluation to enhance professional practice. Association for Supervision and Curriculum Development.

Cyril, A. V. (2015). Time management and academic achievement of higher secondary students. Journal on School Educational Technology, 10(3), 38-43.

Danielson, C. (2013). The framework for teaching evaluation instrument. NJ: Princeton.

De Guzman Jr., R. L., \& Guy, I. A. (2013). Teacher's time management and student's academic achievement in LPU College of nursing: basis for an enhanced classroom management. E - International Scientific Research Journal, 5(3), 225-236.

Dessler, G. (2008). Human resource management. Upper Saddle River, NJ: Pearson Prentice Hall.

Donnelly, R., \& Fitzmaurice, M. (2005). Designing modules for learning. In: emerging issues in the practice of university learning and teaching, O'Neill, G et al. Eds. Dublin: AISHE.

Filgona, J., Sakiyo, J., \& Gwany. D. M. (2020). Teachers' pedagogical content knowledge and students' academic achievement: A theoretical overview. Journal of Global Research in Education and Social Science, 14(2), 14-44.

Gayef, A., Tapan, B., \& Sur, H. (2017). Relationship between time management skills and academic achievement of the students in vocational school of health services. Hacettepe Sağlık İdaresi Dergisi. 20, 247-257.

GoK. (2010). Constitution of Kenya 2010. Nairobi: National Council for Law Reporting.

Golob. H. M. (2012). The impact of teachers' professional development on the results of pupils at national assessment of knowledge. Procedia Social and Behavioral Sciences, 47, 1648-1654.

Hai-Jew, S. (2020). Online survey design and data analytics: Emerging research and opportunities: IGI Global.

Jonyo, D. O., \& Jonyo, B. O. (2017). Management in Kenyan public schools: implications and challenges. European Journal of Educational Sciences, EJES, 4(3).

Juerges, H., Richter, W. F., \& Schineider, K. (2004). Teacher quality and incentives theoretical and empirical effects of standards on teacher quality, presented at CESifo area conference on public sector economics, May 1-22, 2004. www.cesifo.de.

Karamanos, X. (2020). The influence of professional development methods on student mathematics performance in New Jersey public elementary schools. Seton Hall University Dissertations and Theses (ETDs). 2732.

Kareithi, M. W. (2018). Effect of performance appraisal system on performance of secondary schools' teachers in Kirinyaga West SubCounty, Kenya, MBA thesis, School of Business, KCA Univ., Nairobi, Kenya.

Karimi, R. M., \& Hussain, S. (2011). Examining the relationship of performance appraisal system and employee satisfaction. International Journal of Business and Social Science, 2(22), 243-247.

Kayode, G. M., \& Ayodele, J. B. (2015). Impacts of teachers' time management on secondary school students' academic performance in Ekiti State, Nigeria. International Journal of Secondary Education; 3(1): pp. 1-7.

Kothari, C. R. (2004). Research methodology: Methods and techniques. New Age International.

Kuluo, G. S. (2018). Impact of teacher training and students' performance among the Kenyan secondary schools: A case study of Narok County, M.Ed. thesis, Faculty of Education, Univ., of Nairobi, Nairobi, Kenya.

Kwedho, F. J. (2015). Effectiveness of performance contracts among secondary school teachers in Nairobi city county, Kenya, M. ed. Thesis, School of Education, Univ., of Nairobi, Kenya.

Locke, E. A., Latham, G. P., \& Erez, M. (1988). The determinants of goal commitment. The Academy of Management Review, 13(1), 2339. https://doi.org/10.2307/258352.

Lu, M., Loyalka, P., Sh, Y., Chang, F., Liu, C., \& Rozelle, S. (2017). The Impact of Teacher Professional Development Programs on Student Achievement in Rural China. Stanford Center for International Development, 1-34.
Metzler, J., \& Woessmann, L. (2010). The impact of teacher subject knowledge on student achievement: evidence from within-teacher within-student variation. The Institute for the Study of Labor, 4999.

Mills, H. R. (2009). Teaching and training: A handbook for instructors. London, UK: Macmillan Publishers.

Morara, G. N. (2018). Influence of teacher performance on learning achievement in public secondary schools in Kisii County, Kenya. International Journal of Education, 10(2). 21-31.

Muraguri, B. W. (2015). Evaluation of performance contract in relation to teachers' job performance in public tertiary institutions in Nyeri County, Kenya, M.Ed. thesis, Kenyatta Univ., Kenya.

Nasrullah, S., \& Khan, M. S. (2015). The impact of time management on the students' academic achievements. Journal of Literature, Languages and Linguistics, 11, 66-71.

Ngisa, F.S., Muriungi, P., \& Mwenda, E. (2017). Impact of child abuse on academic performance of pupils in public primary schools in Kieni West Sub-County, Nyeri County. International Journal of Business and Management Invention. 6(9), 62-72.

Ngowo, A. A. (2013). Relationship between time management and academic performance for primary schools: A case study of Morogoro Municipality. Msc HRM-Dissertation, Mzumbe Univ., Mzumbe Tanzania.

Odunga, E. W., Ogula, P., \& Nganzi, C. (2020). Effects of teacher quality appraisal scores on students' academic achievement in secondary schools in Baringo North Sub-County, Kenya. The International Journal of Humanities \& Social Studies, 8(9), 236-252.

Ogula, P. A., Ogoti, E. O., \& Maithya, P. M. (2018). Educational and Social Science Research Advanced Short Course: A Guide for Facilitators. Nairobi: Society of Educational Research and Evaluation in Kenya.

Okumbe, J. A. (1999). Educational Management: Theory and Practice. Nairobi, Kenya: University of Nairobi Press.

Olosehinde-Williams, F., Yahaya, L., \& Olowabi, H. (2018). Teachers' knowledge indices as predictors of secondary school students' academic achievement in Kwara State Nigeria. Journal for Education, 6(1), 73-90.

Oluwole, M. U., Idkwu, I. O., Bawa, Y. J., \& Owobu. J. (2017). Influence of teachers' professional development on students' academic achievement in secondary schools in Benue and Nasarawa State, Nigeria. International Journal of Academia, 4(1).

Orodho, J. A., Khatete, I., \& Mugiraneza, J. P. (2016). Concise statistics: An Illustrative Approach to Problem Solving, Nairobi: Kanezja Publishers.

Orodho, J.A. (2017). Techniques of writing research proposals and reports in education and social sciences: An Illustrative Guide to Scholarly Excellence. Nairobi: Kanezja Publishers.

Oso, W.Y. (2016). Social Sciences Research; Principles and Practices. Nairobi: Jomo Kenyatta Foundation.

Oyuga, P. A., Raburu, P., \& Aloka, P. J. O. (2016). Relationship between time management and academic performance among orphaned secondary school students of Kenya. International Journal of Applied Psychology, 6(6), 171-178.

Parish, D. A. (2013). The impact of professional development on student achievement as measured by math and science curriculum-based assessments. Ph.D. Dissertation, Univ. of North Texas.

Razali, S. N., Rusiman, M. S., Gan, W. S., \& Arbin, N. (2018). The impact of time management on students' academic achievement, Journal of Physics: IOP Conf. Series 995, 1-8.

Sangoseni, O., Hellman, M., \& Hill, C. (2012). Development and validation of a questionnaire to assess the effect of online learning on behaviors, attitude and clinical practices of physical therapists in United States regarding evidence-based practice. Journal Allied Health Science Practice, 11, 1-12.

Saunders, M., \& Lewis, P., Thornhill, A., \& Bristow, A. (2019). Research Methods for Business Students", $8^{\text {th }}$ ed. London, UK: Pearson Education Limited, Ch. 4.

Sekaran, U., \& Bougie, R. (2010). Research methods for business: A skillbuilding approach, 5th ed. Haddington: John Wiley \& Sons.

Smith, W. C., \& Kubacka, K. (2017). The Emphasis of Student Test Scores in Teacher Appraisal Systems. Education Policy Analysis Archives, 86. https://doi.org/10.14507/epaa.25.2889.

Surbhi, S. (2015). Difference between performance appraisal and performance management. [online] http://keydifferences.com/.

Tchoshanov, M., Lesser, M., \& Salazar, J. (2008). Teacher knowledge and student achievement: Revealing patterns. NCSM Journal, 39-49.

Teachers Service Commission. (2012). Teachers' performance appraisal report: tpar_revised_dec_20 $0^{\text {th }}$ comm_website.pdf.

Teachers Service Commission. (2016). Teacher performance appraisal and development tool. TSC website.pdf.

Teachers Service Commission. (2018). The era of transformative change: teacher appraisals and PCs the new reform drivers. (K. Kamotho, Ed.) Teachers' Image, (21), 66. 
Young, S. (2009). Supporting and supervising teachers working with adults learning English. Washington, DC: Center for Applied Linguistics.

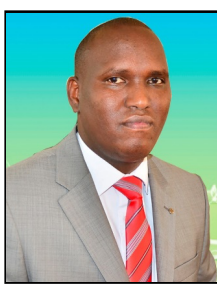

S. Letangule a Kenyan born holds $\mathrm{Ph} . \mathrm{D}$. degree in Business Administration (Strategic Management) (2019) from Jomo Kenyatta University of Technology in Nairobi, Kenya. Master of Business Administration (MBA) (2010) from the Kenya Methodist University and Bachelor of Arts degree from the University of Nairobi.

He has previously worked at the Kenyan Judiciary

of Home Affairs. and the Office of the Vice President and Ministry

He is currently the Director of Kenya School of Government, Baringo Campus in Kenya, he has published more than ten articles in refereed journals in topical areas in strategic management, performance management, innovation and general leadership.

Dr. Letangule is a full member of the Kenya Institute of Management (KIM) and the Kenya Institute of Directors.

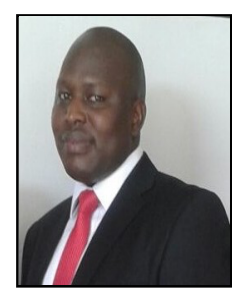

K. M. Chirchir a Kenyan born holds Ph.D. degree in Business Administration and Management (2019) from Dedan Kimathi University of Technology in Nyeri, Kenya. He has previously worked as a Technical College Principal at Guru Nanak Nishkam Sewak Jatha, an Assistant Lecturer at Nairobi, Kenyatta, Kabianga, Embu and Chuka Universities in Kenya spanning over 15 years. He is currently a Principal Lecturer at the Kenya School of Government, Baringo Campus in Kenya, he has published more than ten articles in refereed journals in topical human resource management, education, and organization management, he is the author of Training Civil Service Personnel at Kenya School of Government: Evaluating Effectiveness, Beau Bassin, Mauritius: LAP LAMBERT Academic Publishing, 2020.

Dr. Chirchir is a full member of the Institute of Human Resource Management (IHRM) and an Associate member of the Kenya Institute of Management. He is currently a member of the Kenya Bureau of Standards technical Committee (TC 166). 